\title{
Formas del exceso. El acto en cuestión (Alejandro Agresti, 1993) y el teatro de Ricardo Bartís"
}

\author{
(4) Jorge Sala \\ CONICET - Universidad de Buenos Aires - Universidad Nacional de las Artes, Argentina \\ jorgesala82@hotmail.com
}

Fecha de recepción: 29/03/2018. Fecha de aceptación: 16/04/2018.

\begin{abstract}
Resumen
El objetivo del trabajo es analizar comparativamente algunos de contacto clave entre el film El acto en cuestión (Alejandro Agresti, 1993) con relación a las propuestas del teatro de la resistencia, particularmente con la obra de Ricardo Bartís Postales argentinas (1988). Se buscará demostrar que ambos directores comparten una misma lógica del exceso que gobierna sus creaciones. Esta se basa en la apelación a elementos de la cultura popular argentina, en la predilección por la superposición de fragmentos y en el vínculo explícito con la literatura de Roberto Arlt. La hipótesis central supone que la utilización de estos recursos permite a ambos artistas establecer una confrontación con las formas cinematográficas y teatrales dominantes, al tiempo que los acerca en función de la existencia de un aire de los tiempos.
\end{abstract}

\section{Forms of Excess. El acto en cuestión (Alejandro Agresti, 1993) and the Theatre of Ricardo Bartís}

\begin{abstract}
This article analyzes comparatively some key contact points between the film El acto en cuestion (Alejandro Agresti, 1993) and the proposals of the theater of resistance, particularly considering the play Postales argentinas (Ricardo Bartís, 1988). It will seek to demonstrate that both directors share the same logic of excess that governs their creations. This logic can be identified in their appeal to elements of popular Argentine culture, their predilection for the superposition of fragments and their explicit connection with Roberto Arlt's literature. The central hypothesis assumes that the use of these resources allows both artists to establish a confrontation with the dominant cinematic and theatrical forms, as well as it brings them together on the basis of the existence of a spirit of times.
\end{abstract}

Palabras clave Agresti; Bartís; Postdictadura; Intermedialidad; Exceso;

El acto en cuestión; Postales argentinas

* Una versión abreviada de este texto fue presentada en el marco del VI Congreso de la Asociación de Estudios en Cine y Audiovisual, en marzo de 2018. Agradezco a Ezequiel Lozano y Alicia Aisemberg sus comentarios, los que ayudaron a mejorar algunas ideas allí esbozadas.

Keywords

Agresti; Bartís;

Postictatorship; Intermediality; Excess;

El acto en cuestión; Postales argentinas 


\section{Introducción}

Hay fenómenos culturales que, aunque no de manera deliberada, manifiestan una proximidad. Pese a tratarse de producciones que comparten una misma trama histórica, su circulación y, más aún, su recepción, tiende a no abordarlas como casos emparentados por una lógica común. Su acercamiento, por ende, solo resulta posible a partir de una lectura posterior (la que formularé aquí, por ejemplo). Con todo, algunos de sus procedimientos permiten pensar en la existencia de un efectivo aire de los tiempos que las familiariza o acaso también las confunde.

Esto es lo que sucede con la filmografía inicial de Alejandro Agresti - particularmente aquella situada entre El amor es una mujer gorda (1987) y Buenos Aires viceversa (1996) - con relación a la producción teatral del denominado "teatro de la resistencia" argentino (Pellettieri, 1998), particularmente en las creaciones de Ricardo Bartís. Agresti y Bartís no se conocieron durante la gestación de sus obras o, por lo menos, no mantuvieron un diálogo manifiesto que se tradujera en un trabajo mancomunado dentro de sus propios proyectos personales. No obstante, los dos comparten un conjunto de rasgos que hacen que sus piezas aparezcan como escrituras basadas en una gramática similar (dato que refiere a la existencia de unos principios coincidentes) y asimismo en unos preceptos artísticos idénticos (cuestión que apunta a vincularlos en función de partícipes de un entramado común). Como ha señalado Omar Calabrese refiriéndose a las posibilidades de una estética neobarroca:

si estamos en condiciones de advertir 'semejanzas' y 'diferencias' entre fenómenos que tienen, por otra parte, una apariencia lejanísima, entonces esto quiere decir que 'hay algo por debajo' que, más allá de la superficie, existe una forma subyacente que permite las comparaciones y las afinidades. Una forma. Es decir, un principio de organización abstraído de los fenómenos que preside su sistema interno de relaciones. (1989: 13)

En lo que sigue indagaré estas conexiones, buscando los núcleos de enlace en las decisiones de puesta en escena y en las articulaciones narrativas que ambos directores llevan a cabo. Debido a la necesidad de concentrar el enfoque en unos casos puntuales, me centraré exclusivamente en El acto en cuestión (1993) y en el vínculo intenso -y al mismo tiempo soterrado- que mantiene con Postales argentinas (1988), aunque el análisis podría extenderse a otros ejemplos. Considero que, tanto la película como el espectáculo, componen una suerte de quintaescencia del estilo de sus artífices, al menos de aquel que se perfiló con fuerza durante estos años. Por otra parte, la elección no es aleatoria: aun cuando se distinguen por ser ejemplares acabados en los que se dan cita los principales recursos desarrollados por sus directores, el film se monta alrededor de una franca teatralidad desplegada en varias de sus operaciones formales. Ambas cuestiones inciden por igual al poner sobre la mesa de una manera subrayada el contacto interdisciplinar que facilita el establecimiento de un examen comparativo.

El acto en cuestión se presenta como un falso biopic en el que se narra la vida de Miguel Quiroga, un desocupado de Buenos Aires, en una época imprecisa que podría asimilarse a los años cuarenta o cincuenta. Quiroga gasta sus días buscando trabajo y visitando las tradicionales librerías de viejo en las que roba ejemplares para leerlos en la pensión en la que convive con su mujer, Azucena. El descubrimiento de un libro extraño titulado Magia y ocultismo lo lleva a poner a prueba uno de los trucos que allí se describen, logrando hacer desaparecer en principio objetos y, luego, personas. Gracias a este número espectacular obtiene fama internacional, emprendiendo un recorrido que lo llevará a Europa y a abandonar su lugar de paria. Junto con el éxito sobreviene la soledad y se incrementa su paranoia a ser descubierto. El final concluye con la derrota del personaje al develarse el secreto de su éxito y su posterior regreso al punto inicial. 


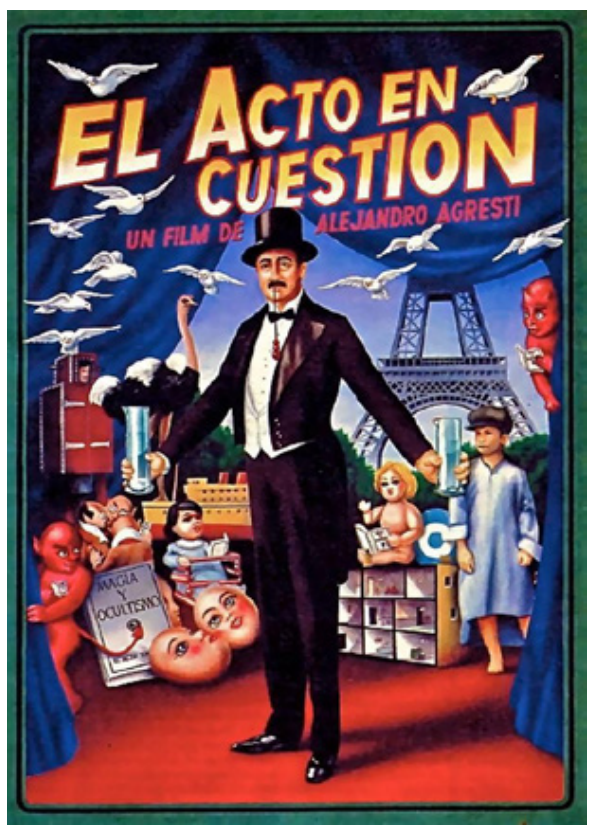

Cartel de la película

Aunque plagada de lugares y tiempos dispersos, de giros climáticos y de fuertes momentos de acción disruptiva, la trama de la película resulta secundaria con relación al lugar preponderante que adquieren sus estrategias de construcción y la sistematización de ciertos elementos recurrentes. En la cita de modelos populares del pasado, en el papel fundamental del fragmento dentro de la articulación audiovisual, así como en el diálogo explícito que el film entabla con la literatura de Roberto Arlt, se articulan los contactos profundos con el universo poético de Bartís. Situados ambos en la encrucijada cultural de los primeros años de la postdictadura, en los que predominaron distintas declinaciones del realismo, su apuesta por el exceso, por una reconocida arbitrariedad en el trabajo de la puesta en escena, los coloca en un lugar de ruptura respecto de las tendencias dominantes.

\section{Agresti y Bartís dentro de la trama cultural de los ochenta}

En gran medida, las prácticas cinematográficas y teatrales surgidas a partir de la recuperación de la democracia en 1983 no pueden dejar de leerse sin que resuenen los ecos de un momento histórico anterior. Las ficciones fílmicas y escénicas estrenadas durante este período hacen visible en sus propuestas las diferentes huellas del horror vivido. Asumiendo formas testimoniales o alegóricas, apelando a una liberación de los cuerpos (en sus versiones más festivas o de sex-plotation), o acudiendo a géneros como el policial o el melodrama, las películas y espectáculos de aquellos años exhalan, al mismo tiempo que una bocanada de apertura a ciertos temas, un hálito amargo y melancólico, producto de los hechos políticos vivenciados en el país.

Al referirse a la intensidad de las relaciones entre las producciones culturales de los ochenta con relación al pasado cercano, Ana Amado describe un mapa común de preocupaciones: "La articulación de mundos discursivos en una trama sociopolítica profundamente afectada por el horror del exterminio de los setenta impuso el sello de la memoria sobre la violencia acontecida a una parte sustantiva de la producción artística argentina, sea fílmica, teatral, literaria, plástica, entre otras" (2009: 12). Siguiendo esta premisa, cabría preguntarse de qué manera se tejió esta alianza entre las ficciones y la historia argentina reciente y cuáles fueron 
las tendencias dominantes o las preguntas principales que las obras pretendieron responder o, al menos, poner sobre la escena. A partir de la delimitación de unos rasgos pregnantes en los films y espectáculos del período podrá examinarse por contraposición el carácter disruptivo que presentan las piezas creadas por Bartís y Agresti.

Trazando unos ejes cardinales a partir de los films, puede constatarse la existencia de dos zonas en la producción cinematográfica. La primera de ellas hizo prevalecer la formulación de respuestas aleccionadoras sobre el pasado inmediato, en tanto otro grupo de películas apuntó a la construcción de unas afirmaciones dirigidas a dar cuenta de una posible identidad colectiva. En los dos casos el pasado dictatorial se presenta como un horizonte, aunque los resultados obtenidos se encausen sobre andariveles diversos, aunque muchas veces complementarios Entonces, mientras el cine realista vinculado a la primera de las tendencias busca lanzar contundentes aseveraciones sobre el testimonial ¿Qué nos pasó?, los vectores narrativos de la segunda se dirigen a contestar un imponderable ¿Cómo somos? atento a delinear los rasgos característicos de los argentinos. En el proceso de reconstrucción de una idiosincrasia global que justificara, al menos potencialmente, lo acontecido en la arena política, estas últimas hurgaron en ciertas bases culturales autóctonas (desde el tango y la literatura al sainete y el grotesco).

En varios sentidos, el teatro realista estrenado en esa década comparte la misma lógica perseguida por el cine hegemónico. Si La historia oficial o La noche de los lápices pueden ser considerados como casos claves de un corpus mayor articulado en torno de la ficcionalización de la historia, películas como Esperando la carroza (Alejandro Doria, 1985) o Sur (Pino Solanas, 1988), aún posicionándose dentro de estéticas dispares, constituyen ejemplos de un modelo pergeñado alrededor de la delimitación de un ser argentino. Espectáculos exitosos como Made in Lanús (1985) de Nelly Fernández Tiscornia - llevada al cine poco después de su estreno por Juan José Jusid- o El viejo criado (1980) de Tito Cossa, comparten con el cine de la transición democrática su ligazón testimonial con relación al pasado inmediato o bien su manifiesto interés por dar cuenta de los principales rasgos definitorios de lo nacional. Según lo señalado por Perla Zayas de Lima al referirse a la pieza de Cossa, en ella sus personajes entablan una relación directa y patente con el universo tanguero e "imponen sus respectivos tiempos interiores al de los hechos de la colectividad social a la que dicen pertenecer y sus historias personales expulsan al exterior y desdibujan la historia del país" (2010: 194). En otras palabras: no es que en la obra los acontecimientos históricos se desvanezcan, sino que estos quedan supeditados a la mostración en primer plano de los comportamientos sociales que los hicieron posibles. El devenir de los sucesos públicos, por lo tanto, aparece como una consecuencia de razones más profundas que serían explicadas a partir del supuesto sernacional.

Como se señaló al principio de este apartado, Agresti y Bartís se recortan dentro de esta trama afianzando su singularidad sobre la base de polemizar con las estéticas dominantes. Contraponiéndose de lo que Rafael Filippelli llamó agudamente el imperio de la realpolitik (1986) ambos creadores consolidaron sus trayectorias iniciales tomando partido por la exacerbación de los materiales de base y haciendo prevalecer la desmesura como un procedimiento central de su hacer artístico. Siguiendo esto, puede verse cómo el gusto compartido por el exceso en la articulación de sus puestas en escena, por el interés común de ordenar la narración a partir del predominio del fragmento, deja entrever un campo de acción en el que se materializa el deseo de contradecir las certezas del relato unívoco sobre el pasado o sobre la propia tradición cultural vernácula. 


\section{Intensidad y maximalismo}

El acto en cuestión toma distancia de las dos tendencias cinematográficas mencionadas antes, aunque de ellas retome despreocupadamente algunos de sus elementos característicos. Si las menciones a las desapariciones realizadas por el mago Miguel Quiroga no pueden leerse sin que aparezcan subterráneamente algunas alusiones al trasfondo dictatorial, las referencias a Borges, a Roberto Arlt o la música de Spinetta permiten sospechar un vaso comunicante con el cine identitario. Sin embargo, lo original de esta película radica justamente en el explícito grado de separación que establece con relación a aquellas películas. El acto en cuestión no se autopostula como testimonio; por el contrario: logra hacer tambalear el registro realista a través de un trabajo con los materiales que constantemente deja al descubierto su carácter de objeto construido.

Reflexionando sobre los films testimoniales del período, el cineasta argumentaba en contra de la redundancia informativa asentada en unos datos ya conocidos por la media de los espectadores: "En La historia oficial perdés una hora para que te expliquen que la protagonista tuvo una amiga que fue torturada, que acá hubo milicos y que la nena... (...) Acá, a mí me gusta decir de entrada: 'ya sabemos dónde estamos, esto no hay que explicarlo'” (Peña, 2003: 48). Una concepción similar esboza Bartís al contraponer dos modalidades de encuentro del teatro con la realidad extraescénica:

existe también un teatro dominante, que es conservador y que trata de mantener la realidad tal y como la realidad se nos muestra y no hace otra cosa que confirmarnos escénicamente aquello que ya sabemos por la formulación de la realidad. (...) Para recuperar entonces la posibilidad de hablar poéticamente, el teatro, en principio, debe aceptar la idea de rasgar, de quebrar, de violentar la realidad" (Bartís, 2003: 147)

En su deseo de postular otro destino para las imágenes, la visión estética de los directores coincide también en la voluntad de construir sus relatos a partir no ya de la linealidad sino de la yuxtaposición de capas de sentido. ¿En qué consiste este gesto confrontador? Básicamente, en la renuncia a la dosificación de las acciones impuesta por las formas en apariencia mesuradas del teatro y el cine realista-testimonial. Frente al desarrollo psicológico, a la concatenación causal de las acciones y a la dialéctica entre contención y distención basadas en el par momento íntimo-encuentro personal, Agresti y Bartís prefieren inclinarse hacia el desborde de los elementos constitutivos de sus elementos visuales y sonoros.

La intención en ambos casos es idéntica. El objetivo es asumir el barroquismo de las puestas en escena como una característica fundante que permite ligar las creaciones a la propia tradición cultural del país. De este modo, mientras Agresti se autoafirma como un cultor de un maximalismo visual y narrativo, Bartís tiende a extremar la artificialidad primordialmente valiéndose de los desempeños de los actores de sus espectáculos. En sus trabajos lo que prima es la acumulación de momentos cargados de una particular intensidad. "La intensidad parece ser para él un excedente,--escribe Luis Emilio Abraham - una desmesura en el trabajo físico o en la carga de actuación que se pone en juego sobre el escenario" (2010: 18).

Maximalismo e intensidad presuponen una misma vía de acción en la cual el exceso opera como denominador común. Esta tendencia al límite que, para Omar Calabrese constituye uno de los rasgos determinantes de las estéticas neobarrocas, enlaza sus propuestas fílmicas y teatrales. En los dos prevalece un ímpetu por tensar los hilos de la narración, partiendo del desorden entendido como antiestructura. Asimismo, también coinciden en otorgar un lugar preponderante a la autoconciencia de los materiales 
como un efecto de sentido que constantemente se repliega sobre sí mismo en un juego de espejos. Pero más que una coincidencia epocal que habilitaría la conexión bajo el paraguas de un Zeitgeist neobarroco, los procedimientos empleados responden al deseo de transgresión de la norma realista. El exceso se transforma de este modo en la estrategia fundamental para reteatralizar el teatro, así como para escapar de un estado en el que el cine "no nos puede decir nada más que lo que hemos leído en los periódicos el día anterior" (Filippelli, 1986: 5).

La actuación aparece como un locus privilegiado a través del cual establecer un punto quiebre respecto de los modelos dominantes. En palabras de Ricardo Bartís: "Nos planteamos la necesidad de recuperar la capacidad de juego en el escenario sin 'componer' personajes desde una formulación psicológica. (...) Nos han atosigado de metodologías o discursos, de saber sobre la actuación y la puesta en escena, que no han servido para producir un teatro vivo, intenso" (Bartís, 2003: 39). El cine, que carga sobre sus espaldas con un lastre realista más grande que el teatro, adopta en El acto en cuestión una resolución idéntica en la búsqueda por abrazar el maximalismo. En la película, las actuaciones de Mirta Busnelli, Carlos Roffé y Lorenzo Quinteros (todas figuras que en mayor o menor medida participaron en el teatro de las transformaciones contrarrealistas de los años setenta y ochenta) demarcan un mismo trayecto. En sus distintas apariciones en pantalla, los actores desarrollan unas composiciones caricaturescas que no pretenden ocultar su condición de artificio. En este sentido, la sistematización de los juegos de palabras que ahondan más en la sonoridad y en la repetición que en la clarificación de un sentido unívoco coadyuvan al despliegue de una gestualidad que renuncia a cualquier estrategia de identificación (o de "identrificación", según enuncia Azucena/Busnelli tocándose los dientes en una escena de la película). Como un reflejo en movimiento de las muñecas que pueblan la clínica del personaje interpretado por Lorenzo Quinteros, los actores de El acto en cuestión aparecen como sujetos cuyos trazos se definen exclusivamente a través de la manipulación de ese director-demiurgo que es Agresti. Carentes, por tanto, de unos matices psicológicos más allá de aquellas marcas provistas por el relato, los actores definen sus movimientos en un puro presente en el que no es posible rastrear las huellas de una historia previa o de motivaciones psicológicas precisas que circunscriban su accionar.

Aún con un escenario despojado, los espectáculos dirigidos por Bartís tendían a sobrecargarse en función de la ampulosidad de los movimientos e incluso tomando partido por una fisicidad deliberadamente contrapuesta a los cánones de belleza. Además de compartir estos rasgos, Pompeyo Audivert, María José Gabín, los protagonistas de Postales argentinas, o Toti Ciliberto (el padre de Hamlet en Hamlet o la guerra de los teatros) construyeron unas imágenes en las que primaba la lógica del exceso a partir de su omnipresencia escénica. Otro tanto cabe para los actores de $E l$ acto en cuestión. El desbordamiento del plano ocasionado por la propia captura de sus gestos por la cámara deja entrever el hecho de que, en la película, tal como sucede en el teatro bartisiano (o bartoliano), "valen más las presencias reales de los actores que las ausencias de la ficción" (Fukelman y Dubatti, 2011: 90-91).

\section{La apelación a modelos culturales pretéritos}

Además de las afinidades que pueden encontrarse al examinar el trabajo con los intérpretes, interesa ver cómo Agresti adapta la demanda de apartarse del realismo recurriendo a procedimientos específicamente fílmicos. Porque, en tanto el tipo de actuación elegida permite observar un vínculo inmediato con lo teatral, las decisiones estilísticas llevadas a cabo por la película plantean un parentesco con la poética de Bartís menos explícita, pero no por ello invisible. 


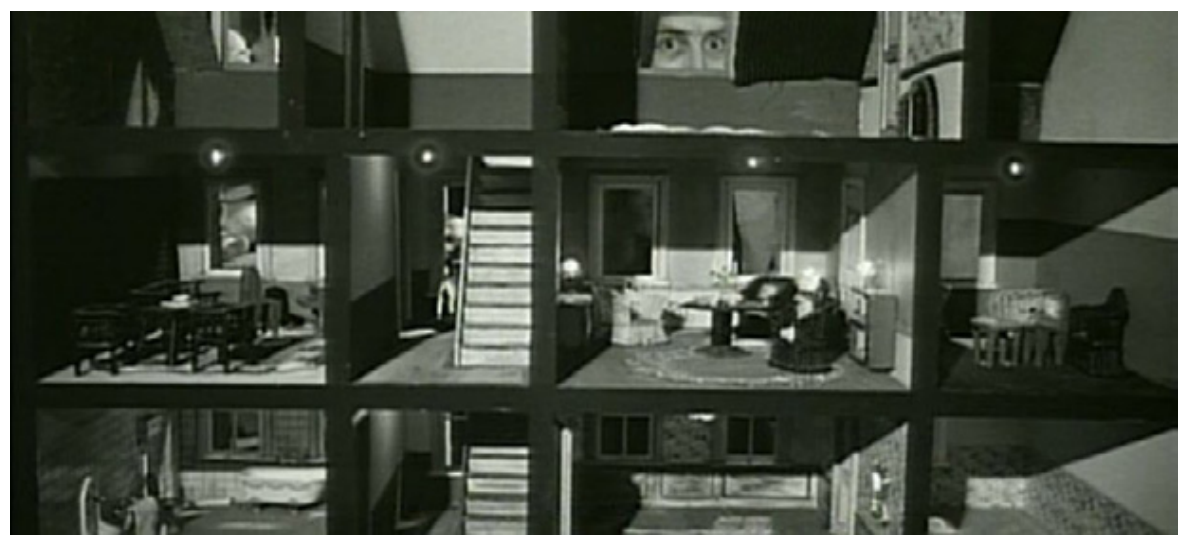

Fotograma de El acto en cuestión - La espacialidad sainetera

Como una impugnación a las tendencias cinematográficas (y teatrales) dominantes, la utilización de sobreexposiciones, del ralentí, el uso del flou óptico o de la desembozada artificiosidad de los decorados apunta en esa dirección. En Agresti, la apelación a estos recursos, más que tender un puente imposible con la vanguardia, postula una clara afinidad con las formas primitivas representadas por las películas de trucajes de Méliès. No se trata solamente de que la biografía de un mago de barrio como la que construye el relato deba ser representada a partir de las alusiones al mago del cine. La elección remite a algo más profundo: establece un vínculo a través del cual la puesta en escena opta por anteponer un anclaje en las formas espectaculares pretéritas claramente identificables por el público. En este reconocimiento de una filiación con el pasado se funda otro puente con los planteos del teatro de la resistencia.

Al igual que en Postales argentinas, dedicada a Pepe Arias, Sandrini, Niní Marshall y Alberto Olmedo, en El acto en cuestión la matriz sainetera se hace presente en el conventillo que habitan Miguel y Azucena, en la proxemia de sus cuerpos recortados por el plano en lenguaje humorístico que predomina en las secuencias iniciales.

De la misma manera que las frases de San Martín o Perón musitadas por Héctor Giraldi en Postales..., las líneas de diálogo del film de Agresti disparan en direcciones diversas, la mayor parte de las veces valiéndose de los desajustes ocasionados por la anacronía. En los dos casos, el flujo de las citas abre el camino a una clase de intertextualidad que torna porosas las categorías de lo alto y lo bajo, diluyendo las diferencias entre la cultura letrada de la popular. Sin embargo, más que de la rapiña aleatoria típicamente posmoderna de la que habla Fredric Jameson, el juego de alusiones que entablan Agresti y Bartís en sus obras busca afincarse en una zona específica de la tradición local. Así, en El acto en cuestión, aunque sus personajes puedan citar a Borges, a Cortázar o a otros escritores consagrados dentro del canon, su modo de hacer principal permanece identificado más cabalmente con las lógicas misceláneas (Aisemberg, 2009) del sainete y del circo, del teatro de variedades y de los entretenimientos considerados menores. Lejos de ser anárquicas, las citas reenvíen sistemáticamente a una zona de la propia historia cultural argentina a través de la cual buscan organizar el horizonte de su mirada. En este sentido, no casualmente gran parte del film de Agresti transcurre con el trasfondo de una pista circense y con un parque de diversiones como motivo visual recurrente; $\mathrm{y}$, asimismo, Postales argentinas, autodefinida desde su mismo título como un sainete de ciencia-ficción. Para ambos autores, entonces, si existe una zona de la historia cultural argentina que funcione como un campo propicio para entablar un orden filiatorio, este se encuentra necesariamente dentro de las formas, y más exactamente, del abanico de gestos y estampas desarrollados al interior de las prácticas espectaculares populares. 


\section{La Argentina como una sumatoria de elementos fracturados}

Es indudable que la última dictadura cívico-militar produjo una ruptura en el tejido social, provocando, a su vez, una herida en el campo de lo simbólico. Partiendo de este estado de catástrofe, la producción artística de los ochenta se articuló en gran medida desde la necesidad de plantearse los modos de reconstrucción de un campo doblemente arrasado. Mientras los modelos realistas teatrales y cinematográficos ensayaron diversas respuestas tendientes a reconfigurar una unidad, para las formas contrahegemónicas esta última aparecía exclusivamente bajo la forma de una quimera. Asumiendo su lugar de escrituras del desastre, Agresti y Bartís afirman con sus producciones la certidumbre de que "la 'falsa' unidad, el simulacro de unidad comprometen a ésta más que su encausamiento directo, el cual, por lo demás, es imposible" (Blanchot, 1990: 10).

El acto en cuestión reniega de toda búsqueda de configuración de una totalidad, no solamente en su explícita reyerta contra el realismo, sino también al desconfiar de las capacidades cicatrizadoras de las alegorías identitarias. $Y$ es en este punto donde la película entabla otro de los enclaves de proximidad al universo teatral de Bartís. Postales argentinas construye su recorrido en torno al amontonamiento y la parcelación de instantes marginales de la historia argentina. Retomando el análisis de Martín Rodríguez:

'la postal', la 'estampa' recupera imágenes arquetípicas que se acumulan en la memoria como en un álbum familiar. Estas imágenes 'queribles', 'entrañables' son rescatadas por Bartís, arrancadas del sistema de valores que las sustenta, despojadas de historia -en el sentido moderno del término-, y proyectadas en un futuro distópico (2000: 115)

Agresti procede de la misma manera con los elementos que conforman el entramado de citas que toman lugar en su película. En ella las referencias a Gatt $\mathcal{E}$ Chaves o al tango, más que anclar temporalmente la narración, provocan la asunción de una lectura afectiva para quien reconoce la procedencia de estos datos.

Ahora bien, independientemente del uso festivo de esta clase de recursos, en otros momentos los instantes fugaces de la realidad o de los discursos ajenos que se insertan en el relato fílmico asumen una tonalidad menos celebratoria. El cineasta extrema en estos casos la potencialidad desarticuladora del fragmento cuando sus personajes mencionan, desprovistas de coordenadas históricas, frases del tipo "aparición con vida" o "en la Argentina, mi país, soy el único que puede hacer desaparecer gente... por ahora". En la operación simultánea de descontextualización y dislocación, El acto en cuestión "consigue un efecto cómico que rompe con las expectativas de un espectador ya acostumbrado a la solemnidad con la que el tema suele ser abordado" (Calcagno y Soriano Barea, 2011:7). En otras palabras, en un momento en que la representación cinematográfica sobre la dictadura alcanzó cierto grado de cristalización repetitiva, Agresti opta por mostrar desde la ironía una voluntad desautomatizadora. Al exponer su carácter de tópico, de saber repetido, el relato devela a su vez esa porción de realidad en la que se compendian los datos de esa identidad nacional difícilmente alcanzable como totalidad.

Con independencia de toda referencialidad política, los directores comparten el gusto por el fragmento entendido como un principio fundamental para comprender (y formar parte de) una genealogía cultural más amplia. Aquí es donde se revela desde otro lugar el papel preponderante que Agresti y Bartís confieren al sainete dentro de sus proyectos personales. Su predilección por lo misceláneo surge como una justificación que permite incluir la propia escritura dentro del sintagma de la historia artística local. Agresti es explícito al respecto cuando afirma que "la 
Argentina es combinación de estilos. Lo que trato de hacer con mis películas es combinar, manosear, dar vuelta, y eso acá es una tradición: la mezcla (...) si puede haber un estilo argentino, está en los ruidos y la mezcla" (Wolf, 1993: 10). Análogamente, para Bartís, la imagen nacional (esa postal argentina a la que alude el título de su espectáculo) solo es posible a través del rescate de una polifonía de voces: "Las palabras que uno ha dicho, las frases que ha leído o que han dicho otros, conviven. Funcionan tipo ventilador: un eje fijo que mueve el aire produciendo pequeños torbellinos. Todo está ahí y al mismo tiempo no es más que aire" (Bartís, 2003: 65). La originalidad de estos proyectos realizados en paralelo se afianza, entonces, en el reconocimiento de que, de la sumatoria de las partes en el marco de una tierra arrasada, no podrá constituirse una nueva totalidad aleccionadora.

La convicción de trabajar con restos, con parcialidades, conlleva necesariamente a una puesta en evidencia de la sospecha sobre la aparente unidad. En los relatos fílmicos y teatrales esta idea clave se traduce en la decisión de explicitar que la realidad circundante no es más que una yuxtaposición de discursos aprehendidos al interior de los relatos mismos. En uno de los tramos de la obra de Bartís, el protagonista pone en duda la veracidad de su propio mundo cuando descubre que este es el producto de una larga serie de citas elaboradas por su madre:

Héctor: (Va hacia adelante y se dirige al público) ¡Comprendí que mi madre citaba! Nada hubiera podido hacerme tanto daño... ¿Qué era lo cierto y qué lo falso en su discurso de madre? ¿Soy yo, en realidad, el que me habito o soy el resultado de las lecturas trasnochadas de mi madre? (Bartís, 2003: 48)

En los últimos tramos de Elacto en cuestión, durante la escena en la que Miguel Quiroga es enjuiciado por apropiarse del truco de magia del libro, su alegato final se aproxima a los argumentos de Héctor Girardi:

Cuán confundidos nosotros estamos a propósito de la realidad. Yo he llevado este truco mágico por los cinco continentes, incluida la Antártida. Miles de millones de personas han visto desaparecer los más diversos objetos con mi péndulo y mis tubos. Por lo tanto, yo he creado lo que aquí esta noche se ha discutido. Pero ahora todos tratan de negarlo. Ustedes, abogados, ¿acaso no han sacado todo lo que saben de libros y ahora lo usan contra mí, como si ustedes fueran los autores? (...) Las cosas, amigos, no pertenecen al que simplemente las enuncia; las cosas pertenecen al que las lleva a cabo. Nada somos, todo lo repetimos, todo lo escuchamos o lo leímos. Ese, queridos amigos, es el verdadero acto en cuestión: el querer creer desesperadamente que somos algo por nosotros mismos.

Los planteos sobre la autoría que subyacen a estas enunciaciones metarreflexivas apuntan a dirimir una operatoria de juego que en Bartís y Agresti resulta idéntica. El proceso de apropiación de los fragmentos ajenos y su puesta en acto - en el trabajo de los actores, en el teatro, en el dispositivo narrativo y audiovisual, en la película- hacen visible una modalidad que busca "destilar los núcleos condensatorios de significados de los textos originarios y detonarlos a través de una poética escénica generadora de nuevos y múltiples asociaciones" (Casullo y Amado, 2004: 172).

\section{La literatura de Arlt como un reservorio común}

En el establecimiento de referencias a textos procedentes de la tradición cultural local, la figura de Roberto Arlt adquiere una relevancia excepcional. No es casual esta elección compartida. Arlt no solamente permite reconstruir una genealogía en 
la que, como dice Borges, cada autor decide determinar su precursor; también ayuda a convalidar la cultura de la mezcla y el gusto por las formas menores que Agresti y Bartís se encuentran desarrollando desde sus propios proyectos artísticos. En otras palabras, la textualidad arltiana opera como un tercer vértice que termina de enlazar unas trayectorias situadas en paralelo debido a que, en este último, se condensa un tipo de escritura construida "con restos, con desechos de la lengua" (Piglia, 2001: 21).

El repertorio de imágenes provisto por las novelas y textos dramáticos del escritor hilvana las preocupaciones de Héctor Girardi (un "oscuro empleado de correos" muy parecido a los personajes de La isla desierta) con las de Miguel Quiroga (una suerte de inventor lumpen, como el Remo Erdosain de Los siete locos). Su condición de outsiders no es el único rasgo que los familiariza con las criaturas arltianas, sino también las tácticas que estos emplean para intentar trascender su situación. En los dos protagonistas hay un manifiesto deseo de salir de pobres que moviliza su accionar y al mismo tiempo los conduce al fracaso. Girardi y Quiroga comparten unas "fantasías sustentadas por el principio de la economía mágica o el gran batacazo como modelo de la movilidad social" (Gilman, 1993: 81) a partir de la escritura obsesiva, en el primero, y la compulsión al robo indiscriminado de libros de poca monta como En el juguete rabioso, en Quiroga.

Ricardo Piglia propone que "en Arlt la ficción se transforma y se metamorfosea y a menudo se identifica con la estafa, con el fraude, con la falsificación, con la delación" (2001: 24). El plagio y la imposibilidad de tomar una voz propia son dos temas que circulan en diversos tramos de Postales argentinas y El acto en cuestión. Cuando escriben, los antihéroes de estas obras solamente pueden repetir discursos ajenos, copiar las novelas ya publicadas. Ya se mencionó el modo en que este tema aparece bajo la forma de una confesión de cara al público (en Bartís) o mediada como un alegato judicial (en Agresti). Arlt funciona, por lo tanto, como un mecanismo propiciatorio para develar el carácter posmoderno de los relatos en tanto promueve el reconocimiento de la imposibilidad de la originalidad al mismo tiempo que la no necesidad de alcanzarla.

Pero, con todo, el acercamiento al escritor ensayado por Agresti y Bartís no se asienta exclusivamente en la conformación de una intertextualidad más o menos reconocible. Ambos directores comparten la misma estrategia dialogal originada en la intención de captar las atmósferas generales de sus obras más que en las citas directas. Cuando en 1998 Bartís estrena El pecado que no se puede nombrar, basada en Los siete locos y Los lanzallamas, explicita este pensamiento en el que, aquello que se busca es, más que los datos de la fábula, su universo ideológico y sus implicancias formales: "Partimos de los textos de las novelas de Arlt, pero no nos quedamos sólo en las palabras, avanzamos sobre la musicalidad de Arlt, el 'fraseo' de su literatura. Nos interesa la singularidad de su escritura, no sólo las historias que cuenta o sus personajes" (Bartís, 2003: 183). No se trata de adaptar, sino de reescribir, pero tomando como base los propios materiales del cine y el teatro: la imagen, las actuaciones, en definitiva: la puesta en escena. Los núcleos principales que unifican los textos de Arlt (el dinero, la locura, la fuerza del complot, la obsesión fetichista) aparecen, entonces, bajo la forma de unas excusas desde las cuales es necesario comenzar a delinear las variantes del propio relato.

\section{Consideraciones finales}

"Para bien o para mal -escribe Leonardo D'Espósito- Alejandro Agresti es un precursor del cine joven e independiente argentino" (2002: 140). Este lugar de antecesor de la renovación que eclosionaría a posteriori conlleva necesariamente otra certeza 
que circula en varios de los artículos dedicados a revisar su trayectoria. Si el director es una suerte de padre (o de tío, junto con Martín Rejtman) lo es a condición del desajuste manifiesto que su obra plantea con relación al contexto cinematográfico en el que esta se dio a conocer. Entonces, mientras sus películas de finales de los ochenta y principios de la década siguiente se recortan como creaciones singulares, incompatibles con las tendencias fílmicas del momento (a menos que se invoquen los criterios de la anticipación) su carácter solitario se magnifica en la medida en que la recepción solo ha tomado en consideración los desenvolvimientos expresados en el campo cinematográfico sin mirar lo que ocurre por fuera de ese territorio específico.

El objetivo de este artículo fue mostrar que, lejos de ser una rara avis, El acto en cuestión detenta unas conexiones patentes con otros objetos artísticos cercanos en el tiempo. Ahora bien, y quizás este sea uno de los problemas de los críticos al analizar la película, este contacto debe buscarse no ya dentro del propio cine, sino observando más allá. Al examinar sus procedimientos narrativos, su lógica de construcción escénica y las referencias a una tradición cultural en relación con una zona de la producción del teatro de la resistencia, específicamente representada por las obras de Ricardo Bartís, sus rasgos característicos plantean una familiaridad que no es otra cosa que la prueba de la existencia de un "aire de los tiempos". En consecuencia, la posibilidad de establecer un enfoque interdisciplinar hace que los rasgos de sus respectivas poéticas parezcan desplegarse en una serie de interpelaciones mutuas, de vinculaciones intensas.

Alberto Ure, uno de los principales defensores de Postales argentinas, describía la originalidad del espectáculo argumentando que "su tema central, mejor dicho el cruce central de sus varios temas, apela con impudor deslumbrante a otras artes y a sus técnicas" (Bartís, 2003: 63). Estas palabras pueden ser fácilmente transportables a una exégesis de El acto en cuestión. En el espacio difuso e intermedial en el que ambas obras se desarrollan, sus resultados se amalgaman como partes de un único engranaje dedicado a confrontar con las prácticas realistas hegemónicas. En esta predilección por el exceso, por la mezcla de discursos, por la acumulación de fragmentos que no pretenden afianzarse en una síntesis superadora, Agresti y Bartís se encuentran como aliados (quizás inconscientes, pero aliados al fin) de una misma batalla. 


\section{Bibliografía}

"Abraham, L. E. (2010). “Preguntas sobre la intensidad (con acento en el campo teatral argentino", telondefondo, (11), [en línea]. Consultado el 22 de marzo de 2018 en <http://www.telondefondo.org/numeros-anteriores/numero11/articulo/28o/preguntas-sobre-la-intensidad-con-acento-en-el-campo-teatral-argentino.html>.

»Aisemberg, A. (2009). “El mundo popular en escena. Formas misceláneas de representación en el sainete criollo", en VV.AA., Concurso nacional de ensayos teatrales “Alfredo de la Guardia”, Buenos Aires, INT y FIBA, pp. 191-337.

" Amado, A. (2009). La imagen justa. Cine argentino y política (1980-2007), Buenos Aires, Colihue.

» Bartís, R. (2003). Cancha con niebla. Teatro perdido: fragmentos, Buenos Aires, Atuel.

"Blanchot, M. (1990). La escritura del desastre, Caracas, Monte Ávila.

"Calabrese, O. (1989). La era neobarroca, Madrid, Cátedra.

»Calcagno, L. y Soriano Barea, G. (2011). “El acto en cuestión. Las posibilidades de la crítica postmoderna”, en Actas del II Congreso Internacional de la Asociación de Estudios en Cine y Audiovisual, [en línea]. Consultado el 24 de febrero de 2018 en <http://www.asaeca.org/aactas/calcagno_luciana_soriano_griselda.pdf>.

»Casullo, L. y Amado, A. (2004). “Entre fábulas y conspiraciones. Texto y traición en Ricardo Bartís", en Pellettieri O. (Ed.) Reflexiones sobre el teatro, Buenos Aires, Galerna, pp. 169-176.

"D’Espósito, L. (2002). “Del cine independiente a la industria: el caso de Agresti”, en VV.AA. Nuevo cine argentino: temas, autores y estilos de una renovación, Buenos Aires, Ediciones Tatanka / FIPRESCI, pp. 133-141.

» Filippelli, R. (1986). “Contra la Realpolitik en el arte”, Punto de vista, N²6, Abril: pp. 5-6.

» Fukelman, M. y Dubatti, J. (2011). “Postales argentinas (1988) de Ricardo Bartís: Dramaturgia de dirección, distopía y muerte del país”, Stichomythia, (11-12), pp. 89-97. [en línea]. Consultado el 23 de marzo de 2018 en <http://parnaseo3.ci.uv. es/Ars/Stichomythia/stichomythia11-12/pdf/estudio_9.pdf>.

» Gilman, C. (1993). “Los siete locos: novela sospechosa de Roberto Arlt”, Cuadernos Hispanoamericanos, Los Complementarios, (11), Julio, pp. 77-94

»Peña, F. M. (2003). Generaciones 60/90, Buenos Aires, Malba/Fundación Constantini.

»Pellettieri, O. (1998). "Modernidad y postmodernidad en el teatro argentino actual” en Pellettieri O. (ed.) El teatro y su crítica, Buenos Aires, Galerna, pp. 147-167.

»Piglia, R. (2001). Crítica y ficción, Barcelona, Anagrama.

» Rodríguez, M. (2000). "La puesta en escena emergente y su futuro", en Pellettieri O. (dir.) Teatro argentino del 2000, Buenos Aires, Galerna, pp. 115-128.

»Wolf, S. (1993). “Agresti. La indisciplinada combinación”, Revista Film, (3), Buenos Aires, Agosto-Septiembre, pp. 9-13.

"Zayas de Lima, P. (2010). El universo mítico de los argentinos en escena, Tomo 2, Buenos Aires, Instituto Nacional de Teatro. 